\title{
PHYSIO-AGRONOMIC CHARACTERIZATION OF UPLAND RICE INOCULATED WITH MIX OF MULTIFUNCTIONAL MICROORGANISMS ${ }^{1}$
}

\author{
JOÃO PEDRO TAVARES FERNANDES ${ }^{2 *}$, ADRIANO STEPHAN NASCENTE ${ }^{3}$, MARTA CRISTINA CORSI DE \\ FILIPPI $^{3}$, ANNA CRISTINA LANNA ${ }^{3}$, VINÍCIUS SILVA SOUSA ${ }^{4}$, MARIANA AGUIAR SILVA ${ }^{4}$
}

\begin{abstract}
Multifunctional microorganisms can contribute significantly to improve plant performance and are innovative technology for sustainable development. Thus, objective of this study was to determine the effect of bioagents applied alone or in mix on the performance of upland rice. The experiment was conducted in a greenhouse in a completely randomized design with four replications. The 26 treatments consisted of the rhizobacteria Bacillus sp. (BRM 32109, BRM 32110 and 1301), Azospirillum sp. (1381), Azospirillum brasilense (Ab-V5), Pseudomonas sp. (BRM 32112), Pseudomonas fluorescens (BRM 32111), Burkholderia pyrrocinia (BRM 32113), Serratia sp. (BRM 32114), and a fungal genus formed by a pool of Trichoderma asperellum (T-06, T-09, T-12, and T-52), applied alone or in mix, plus a control treatment without microorganism application. The most effective treatments were the mixes of microorganisms $1301+\mathrm{Ab}-\mathrm{V} 5$ and BRM 32114 + pool of Trichoderma asperellum, as they provided an average increase of 123 and $88 \%$ in the number of panicles and 206 and $167 \%$ in the grain yield of upland rice plants, respectively. Mixes of 1301 + Ab-V5, BRM 32114 + Trichoderma asperellum pool, BRM 32110 + BRM 32114, BRM 32110 + Ab-V5, $1301+$ BRM 32110 and 1381 + Trichoderma asperellum pool also provided better morphophysiological performance in rice plants (photosynthetic rate, carboxylation efficiency, number of tillers, shoot dry biomass and nutrient content in shoot and root). Therefore, the use of multifunctional microorganisms in the management of upland rice was efficient in its ability to provide better development of plants.
\end{abstract}

Keywords: Oryza sativa L. Inoculation. Sustainability. Growth promoters.

\section{CARACTERIZAÇÃO FISIO-AGRONÔMICA DO ARROZ DE TERRAS ALTAS INOCULADO COM MIX DE MICRORGANISMOS MULTIFUNCIONAIS}

RESUMO - Microrganismos multifuncionais podem contribuir significativamente para melhorar o desempenho das plantas, sendo tecnologia inovadora quando se visa o desenvolvimento sustentável. Assim, objetivou-se determinar o efeito de microrganismos multifuncionais aplicados isolados ou em mix sobre o desempenho do arroz de terras altas. O experimento foi conduzido em casa de vegetação, em delineamento inteiramente casualizado, com quatro repetições. Os 26 tratamentos consistiram das rizobactérias Bacillus sp. (BRM 32109, BRM 32110 e 1301), Azospirillum sp. (1381), Azospirillum brasilense (Ab-V5), Pseudomonas sp. (BRM 32112), Pseudomonas fluorescens (BRM 32111), Burkholderia pyrrocinia (BRM 32113), Serratia sp. (BRM 32114), e um gênero fúngico formando um pool de Trichoderma asperellum (T-06, T-09, T-12, e T52), aplicados isoladamente ou em consórcio, mais o tratamento controle, sem aplicação de microrganismos. Os tratamentos mais efetivos foram os mixes de microrganismos $1301+$ Ab-V5 e BRM $32114+$ pool de Trichoderma asperellum, uma vez que proporcionaram aumento, em média, de $123 \%$ e $88 \%$ no número de panículas e de 206 e $167 \%$ na produtividade de grão do arroz de terras altas, respectivamente. Os consórcios $1301+$ Ab-V5, BRM $32114+$ pool de Trichoderma asperellum, BRM $32110+$ BRM 32114, BRM $32110+$ Ab -V5, 1301 + BRM 32110 e 1381 + pool de Trichoderma asperellum, também proporcionaram maior desempenho morfofisiológico nas plantas de arroz (taxa fotossintética, eficiência de carboxilação, número de perfilhos, biomassa seca de parte aérea e teor de nutrientes na parte aérea e raiz das plantas). Portanto, o uso de microrganismos multifuncionais no manejo do arroz de terras altas foi eficiente em sua capacidade de proporcionar maior desenvolvimento das plantas.

Palavras-chave: Oryza sativa L. Inoculação. Sustentabilidade. Promotores de crescimento.

\footnotetext{
${ }^{*}$ Corresponding author

${ }^{1}$ Received for publication in 11/05/2019; accepted in 05/27/2020

Paper extracted from the master dissertation of the first author.

${ }^{2}$ School of Agronomy, Universidade Federal do Paraná, Curitiba, PR, Brazil; joaopedroagronomo@gmail.com - ORCID: 0000-0003-21626654 .

${ }^{3}$ Brazilian Agricultural Research Corporation, Embrapa Arroz e Feijão, Santo Antônio de Goiás, GO, Brazil; adriano.nascente@embrapa.br - ORCID: 0000-0002-6014-3797, cristina.filippi@embrapa.br - ORCID: 0000-0003-1676-8164, anna.lanna@embrapa.br - ORCID: 00000001-8018-9349.

${ }^{4}$ School of Agronomy, Universidade Federal de Goiás, Goiânia, GO, Brazil; viniciusagro78@gmail.com - ORCID: 0000-0002-5387-4997, marianaaguiar23@hotmail.com - ORCID: 0000-0003-0297-5576.
} 


\section{INTRODUCTION}

Upland rice, grown mostly in the Midwest and North regions of Brazil, is dependent on rainwater and contributes to 1.3 million tons $(11 \%$ of Brazilian production) compared to the production by flooding (11 million tons, 89\% of Brazilian production) (EMBRAPA, 2019). Even with this low contribution to the total rice production in the country, cultivation of the upland rice is an alternative for the increase of national production. However, increasing upland rice yield is a challenge for research considering biotic and abiotic stresses, such as the occurrence of diseases, prolonged periods of drought, nutritional deficiency, as well as problems with the initial seedling emergence and plant growth, mainly in no-tillage areas (FILIPPI et al., 2011).

Considering the perspective of growth population and, consequently, the increase demand for rice grain, it is essential to increase its production in a sustainable way (DEVKOTA et al., 2019). In this sense, the use of multifunctional microorganisms in rice crop can represent a management option with the purpose to promote plant growth by increasing nutrient availability from the soil, the efficiency of gas exchange and, consequently, the production of greater amount of phytomass and grain yield (GODFRAY et al., 2012; NASCENTE et al., 2017a). Studies carried out at Embrapa Rice and Beans in partnership with the Federal Rural University of the Amazon showed the multifunctional role of microorganisms, especially rhizobacteria and fungi of the genus Trichoderma asperellum, in association with rice plants. Results from a greenhouse experiment showed that among the multifunctional microorganisms studied, the isolated Serratia sp. was the most effective in promoting an increase in the photosynthetic rate, greater accumulation of nutrients and shoot biomass in upland rice plants in the genotype derived from BRS Primavera CL (NASCENTE et al., 2017a). In another experiment, conducted by Sperandio et al. (2017), evaluating the growth of upland rice plants measured by leaf area, length and shoot and root biomass, they also concluded that there were better results in plants inoculated with Serratia sp. Besides, in this same study, resistance to pathogens was induced by both Serratia sp. and Bacillus sp. (BRM 32110). In addition, other genera of multifunctional microorganisms, such as Burkoholderia and Pseudomonas, have been studied in agricultural crops and their beneficial effects on plant development have been reported (OLIVEIRA et al., 2019; MATOSO et al., 2020).

From these results of previous research, questions arose such as: (a) "could the use of multifunctional microorganisms mixed provide even better results than their application alone?" (b) "could other microorganisms provide even better results than those presented by the microorganisms already tested?" Thus, the objective of this study was to determine the effect of multifunctional microorganisms, isolated or in mix, on the performance of upland rice plants.

\section{MATERIAL AND METHODS}

\section{Site characterization}

The experiment was conducted in greenhouse conditions, from September to December 2018, at Capivara Farm of Embrapa Rice and Beans, located in the municipality of Santo Antônio de Goiás, Goiás, Brazil. The soil used came from the arable layer $(0-0.20 \mathrm{~m})$ of a Red Oxisol (SANTOS et al., 2018), of medium texture. Before the installation of the experiment, the soil fertility analysis was performed, which had the following characteristics: $\mathrm{pH}\left(\mathrm{H}_{2} \mathrm{O}\right)=6.1 ; \mathrm{Ca}^{2+}=78.4 \mathrm{mmol}_{\mathrm{c}} \mathrm{dm}^{-3} ; \mathrm{Mg}^{2+}=$ $20.9 \mathrm{mmol}_{\mathrm{c}} \mathrm{dm}^{-3} ; \mathrm{H}+\mathrm{Al}^{3+}=12 \mathrm{mmol}_{\mathrm{c}} \mathrm{dm}^{-3} ; \mathrm{P}=$ $35.9 \mathrm{mg} \mathrm{dm}^{-3} ; \mathrm{K}^{+}=203 \mathrm{mg} \mathrm{dm}^{-3} ; \mathrm{Cu}^{2+}=2.4 \mathrm{mg} \mathrm{dm}^{-}$ ${ }^{3} ; \mathrm{Zn}^{2+}=2.9 \mathrm{mg} \mathrm{dm}{ }^{-3} ; \mathrm{Fe}^{3+}=39 \mathrm{mg} \mathrm{dm}{ }^{-3} ; \mathrm{Mn}^{2+}=28$ $\mathrm{mg} \mathrm{dm}{ }^{-3}$ and Organic matter $=24.7 \mathrm{~g} \mathrm{~kg}^{-1}$. These analyzes followed the methods proposed by Donagema et al. (2011).

\section{Experimental design and treatment}

The experimental design was a completely randomized with 26 treatments and four replications. The treatments consisted of suspensions of microorganisms, isolated or in mix, plus the control treatment (without microorganisms). The multifunctional microorganisms used for the composition of the treatments were: isolates from Bacillus sp. (BRM 32109, BRM 32110 and 1301), Pseudomonas fluorescens (BRM 32111), Pseudomonas sp. (BRM32112), Burkholderia pyrrocinia (BRM 32113), Serratia sp. (BRM32114), Azospirillum sp. (1381), Azospirillum brasilense (Ab -V5) and Trichoderma asperellum isolate pool ( $\mathrm{T}$ 06, T-09, T-12, and T-52).

\section{Microorganisms application}

All microorganisms, isolated or in mix, were applied at three times in the rice crop: 1. Seed microbiolization; 2. Microorganism suspension applied in the soil at 7 days after sowing (DAS); 3 . Microrganism suspension applied to the rice shoots at 21 DAS. The bacterial isolates are part of microorganisms collection from Embrapa Rice and Beans and the pool of $T$. asperellum isolates is part of the fungi collection of the Federal Rural University of the Amazon. The biochemical characteristics and taxonomic classification of rhizobacteria are available in Nascente et al. (2017a) and the T. asperellum pool in Silva et al. (2011). 


\section{Preparation of microorganism solutions}

From cultures growing on solid medium (nutrient agar), suspensions with the microorganisms were prepared in liquid medium 523 (nutrient broth) (KADO; HESKETT, 1970), in a shaking incubator, for 24 hours at $28{ }^{\circ} \mathrm{C}$. The suspension concentration of each microorganism was adjusted in a spectrophotometer to $\mathrm{A} 540=0.5$, which corresponds to $1 \times 10^{8}$ colony-forming units $(\mathrm{CFU})$ per $\mathrm{mL}$. The mix treatments were composed by joining equal parts of the suspension of the multifunctional microorganism isolates. Before microbiolization, the seeds were disinfected with immersion in $70 \%$ alcohol for one minute and $0.05 \%$ sodium hypochlorite for the same period of time, followed by drying at room temperature at $29{ }^{\circ} \mathrm{C}$. Microbiolization occurred with the immersion of the seeds in suspensions of each microorganism and the control treatment, by immersing the seeds in water, for 24 hours at a temperature of $25{ }^{\circ} \mathrm{C}$, under constant agitation, according to the methodology proposed by Filippi et al. (2011). Microbiolization with a pool of $T$. asperellum used viable conidia, multiplied in the microbiology laboratory of Embrapa Rice and Beans. Each T. asperellum isolate was grown in a Petri dish containing PAD (potato and agar dextrose) for five days and bioformulated as described by Silva et al. (2012). Seed treatment occurred with $10 \mathrm{~g}$ of powdered $T$. asperellum conidia (SILVA et al., 2012), for $1 \mathrm{~kg}$ of seeds (FILIPPI et al., 2011). The concentration of the biological suspension was $10^{8}$ conidia $\mathrm{mL}^{-1}$, which was transferred to a plastic bag, along with the seeds. The bags were shaken to homogenize the seeds, according to the methodology proposed by (FRANÇA et al., 2015).

At seven DAS, it was applied $100 \mathrm{ml}$ of suspension $\left(10^{8} \mathrm{CFU}\right)$ of each bacterium, or with suspension containing the pool of $T$. asperellum $\left(10^{8}\right.$ conidia. $\left.\mathrm{mL}^{-1}\right)$ or with distilled water (control) in the soil. At $21 \mathrm{DAS}$, it was applied to the rice plant $30 \mathrm{ml}$ of bacteria suspension $\left(10^{8} \mathrm{CFU}\right)$, or with the pool of $T$. asperellum $\left(10^{8}\right.$ conidia. $\left.\mathrm{mL}^{-1}\right)$, or with distilled water (control). The equipment used for application in the plants was a manual sprayer, with $\mathrm{CO}_{2}$ pressure, with a conical type nozzle (TXVS2), washed with water and liquid detergent and disinfected with 70\% alcohol, between the applications of each treatment.

\section{Rice management}

In the experiment, upland rice seeds cultivar BRS A501 CL were used. This cultivar is resistant to the broad spectrum herbicide Kifix ${ }^{\circledR}$, it has medium life cycle, high stability in whole grain in processing, good general resistance against diseases and high grain yield potential (EMBRAPA, 2018). Thus, three weeks before rice sowing, all $7 \mathrm{~kg}$ plastic pots were completely filled with soil and fertilized with $70 \mathrm{mg} \mathrm{dm}^{-3}$ of $\mathrm{N}$ (urea), $400 \mathrm{mg} \mathrm{dm}^{-3}$ of $\mathrm{P}_{2} \mathrm{O}_{5}$ (simple superphosphate) and $200 \mathrm{mg} \mathrm{dm}^{-3}$ of $\mathrm{K}_{2} \mathrm{O}$ (potassium chloride). Ten microbiolized rice seeds were sown per pot. Seedling emergence occurred at six days after sowing (DAS) and plant thinning was performed at seven days after emergence (DAE) to keep two plants per pot. During tillering (28 DAE) and floral primordium stage (48 DAE), nitrogen fertilization (two grams of ammonium sulphate) and potassium (one gram of potassium chloride) were carried out in each pot. The weed control was performed manually, weekly, and there was no intervention to control pests and diseases during the experiment. Saturated soil was kept throughout the cropping period with daily irrigation frequency.

\section{Variables \\ Gas exchange}

At 96 DAE (full flowering), gas exchanges were determined using the portable gas meter in the IRGA infrared region (LCpro+, ADC BioScientific). Thus, the following evaluations were carried out: photosynthetic rate (A, $\mu \mathrm{mol} \quad \mathrm{CO}_{2} \quad \mathrm{~m}^{-2} \mathrm{~s}^{-1}$ ); transpiratory rate $\left(\mathrm{E}, \mathrm{mmol} \mathrm{H}_{2} \mathrm{O} \mathrm{m} \mathrm{m}^{-2} \mathrm{~s}^{-1}\right)$; stomatal conductance (gs, mol $\mathrm{H}_{2} \mathrm{O} \mathrm{m} \mathrm{m}^{-2}$ ); internal $\mathrm{CO}_{2}$ concentration $\left(\mathrm{Ci}, \mu \mathrm{mol} \mathrm{mol}{ }^{-1}\right)$ and leaf temperature (Tfoliar, ${ }^{\circ} \mathrm{C}$ ). The instant carboxylation efficiency (EiC) was calculated by the ratio between $\mathrm{A}$ and $\mathrm{Ci}$ $\left.\left[\left(\mu \mathrm{mol} \mathrm{m} \mathrm{m}^{-2} \mathrm{~s}^{-1}\right)(\mu \mathrm{mol} \mathrm{mol})^{-1}\right)^{-1}\right]$ according to the methodology described by Silva et al. (2013). The evaluation period was between $8: 30$ am to $10: 30 \mathrm{am}$. At 95 and 96 DAE (stage R3, 50\% of total upland rice plants in bloom), with leaf temperature (Tfoliar) ranging from 31.19 to $38.65{ }^{\circ} \mathrm{C}$, with an average of $33{ }^{\circ} \mathrm{C}$. The readings were taken in the central third of the first fully expanded leaf (from top to bottom) in the rice plants. The IRGA chamber remained regulated with concentrations of $370-400 \mu \mathrm{mol} \mathrm{mol}^{-}$ $1 \mathrm{CO}_{2}$ (reference), with a density of photosynthetically active photon flux (DFFFA) of $1200 \mu \mathrm{mol}$ [quanta] $\mathrm{m}^{-2} \mathrm{~s}^{-1}$.

\section{Dry shoot and root biomass}

At 120 DAE, the upland rice shoots was cut, the number of tillers per pot was counted and the fresh shoot biomass was packed in natural kraft paper envelopes that were properly identified. For the rice roots, these were separated by plot and washed with water, after the cleaning process they were packed in natural kraft paper bags. Both the shoots and the roots were taken to dry in a forced ventilation oven, at $65{ }^{\circ} \mathrm{C}$, until constant biomass. Then, the material in each envelope was weighed to 
determine dry shoot and root biomass. Thus, the parameters of number of tillers (NT, unit), dry shoot biomass (DSB, g pot ${ }^{-1}$ ), dry root biomass (DRB, $\mathrm{g} \mathrm{pot}^{-1}$ ) and total dry biomass (TDB, g pot ${ }^{-1}$ ) was determined.

\section{Shoot and root macro nutrients}

At 120 DAE, the aerial part and roots of upland rice plants, of each treatment, after drying and weighing, were ground in a Willey mill for the analysis and determination of nutrient contents $(\mathrm{N}, \mathrm{P}$, $\mathrm{K}$ ), of according to Malavolta, Vitti and Oliveira (1997).

\section{Yield components and grain yield}

At 120 DAE the agronomic characteristics: grain yield (PROD, $\mathrm{g} \mathrm{pot}^{-1}$ ), number of panicles per pot (NPP, unit), number of grains per panicle (NGP, unit) and mass of 1000 grains $(1000 \mathrm{M})$ were determined. Grain yield was determined by weighing the samples collected in each plot, and the moisture content of the grains was corrected to $13 \%$ wet basis and converted to $g \operatorname{pot}^{-1}$. The NPV was determined by adding the total number of panicles per pot. Likewise, NGP was obtained by counting the total number of grains, divided by the total number of panicles per pot. To obtain the $1000 \mathrm{M}$ values, the total number of grains was counted and their mass was determined. Thus, after correcting the moisture content of the grains to $13 \%$, wet basis, as a rule of three simple, the mass of 1000 grains was calculated.

\section{Statistical analysis}

Firstly, the determination of the normality of errors (Shapiro-Wilk test) and the homogeneity of variance (Bartlett test) was performed. Then, the data were subjected to analysis of variance and, when significance was detected, the means were compared using the LSD test $(\mathrm{p} \leq 0.05)$. The SAS statistical package was used to process these data. Additionally, a multivariate principal component analysis (PCA) was performed to describe the correlation between response variables (gas exchange, shoot, root and total biomass, accumulation of nutrients in the shoot and roots, yield components and grain yield) with isolated and mixed microorganisms. The main components (MCs) were loaded with response variables when the correlation test produced $r \geq 0.50$. The first three MCs responsible for $>62 \%$ of the data variation were maintained. Biplots (two-dimensional graph) using these three MCs that correlate isolated and mixed microorganisms and response variables were built with the "FactoExtra" package (KASSAMBARA, 2015) on the R platform.

\section{RESULTS AND DISCUSSION}

The inoculated and non-inoculated plants showed the same pattern of gas exchange (Figure 1). Additionally, it was observed that the treatments 1381 (Azospirillum sp.) + BRM 32110 (Bacillus sp.) and Pseudomonas fluorescens (BRM 32111) provided higher values in photosynthesis (14.92 and $14.89 \mu \mathrm{mol} \mathrm{CO}_{2} \mathrm{~m}^{-2} \mathrm{~s}^{-1}$ ), however, there was no significant difference compared to the control treatment. As well as, the highest values for transpiration, stomatal conductance and internal $\mathrm{CO}_{2}$ concentration, were obtained with the BRM $32110+$ $\mathrm{Ab}-\mathrm{V} 5$ treatment, with $\mathrm{E}\left(6.13 \mathrm{mmol} \mathrm{H}_{2} \mathrm{O} \mathrm{m}^{-2} \mathrm{~s}^{-1}\right)$, gs $\left(0.270 \mathrm{~mol} \mathrm{H}_{2} \mathrm{O} \mathrm{m}^{-2} \mathrm{~s}^{-1}\right)$ and $\mathrm{Ci}\left(271 \mu \mathrm{mol} \mathrm{mol}^{-1}\right)$ in rice plants, likewise, did not differ from the control treatment. In addition, the highest value in instant carboxylation efficiency (EiC) was obtained using the 1381 + BRM 32110 treatment, although it does not differ significantly from the control treatment. These results may indicate that the microorganisms used had little effect on gas exchange in upland rice plants. Nascente et al. $(2017 \mathrm{a}, \mathrm{b})$ also reported that the microorganisms did not provide major changes in gas exchange in relation to the control treatment, however they did provide significant increases in rice production.

There was a significant increase in the number of tillers $(59 \%$, on average) in upland rice plants treated with the mixed application of 1301 (Bacillus spp.) + Ab-V5 (A. brasilense) and BRM 32114 (Serratia sp.) + pool of T. asperellum, which differed from the control treatment, and did not differ from treatments with isolated application of Azospirillum brasilense (Ab-V5), and from the mixed application of $1301+$ Pool of $T$. asperellum, $1301+$ BRM 32110, 1381 + Pool of T. asperelllum (Figure 2). Tilling in rice crop is desirable, according to Yoshida (1981), this is a characteristic that is directly related to the production of grains and also to the biomass of the plants. In the present work, it appears that the largest increments in number of tillers were obtained with plants treated with some multifunctional microorganisms in comparison to the control. In addition, those plants that profiled more also had higher values of dry shoot biomass and total biomass, being able to influence positively in the number of panicles and in the grain yield. Thus, the largest accumulation of shoot biomass of upland rice plants was obtained with plants treated with BRM $32114+$ Pool of T. asperellum, $1301+$ Ab-V5 and $1301+$ BRM 32110, respectively, differing significantly from the control treatment. This result corroborates research developed by Nascente et al. (2017a, b) and Sousa, Nascente and Filippi (2019), who observed an increase in dry shoot biomass in the rice crop provided by multifunctional microorganisms. 

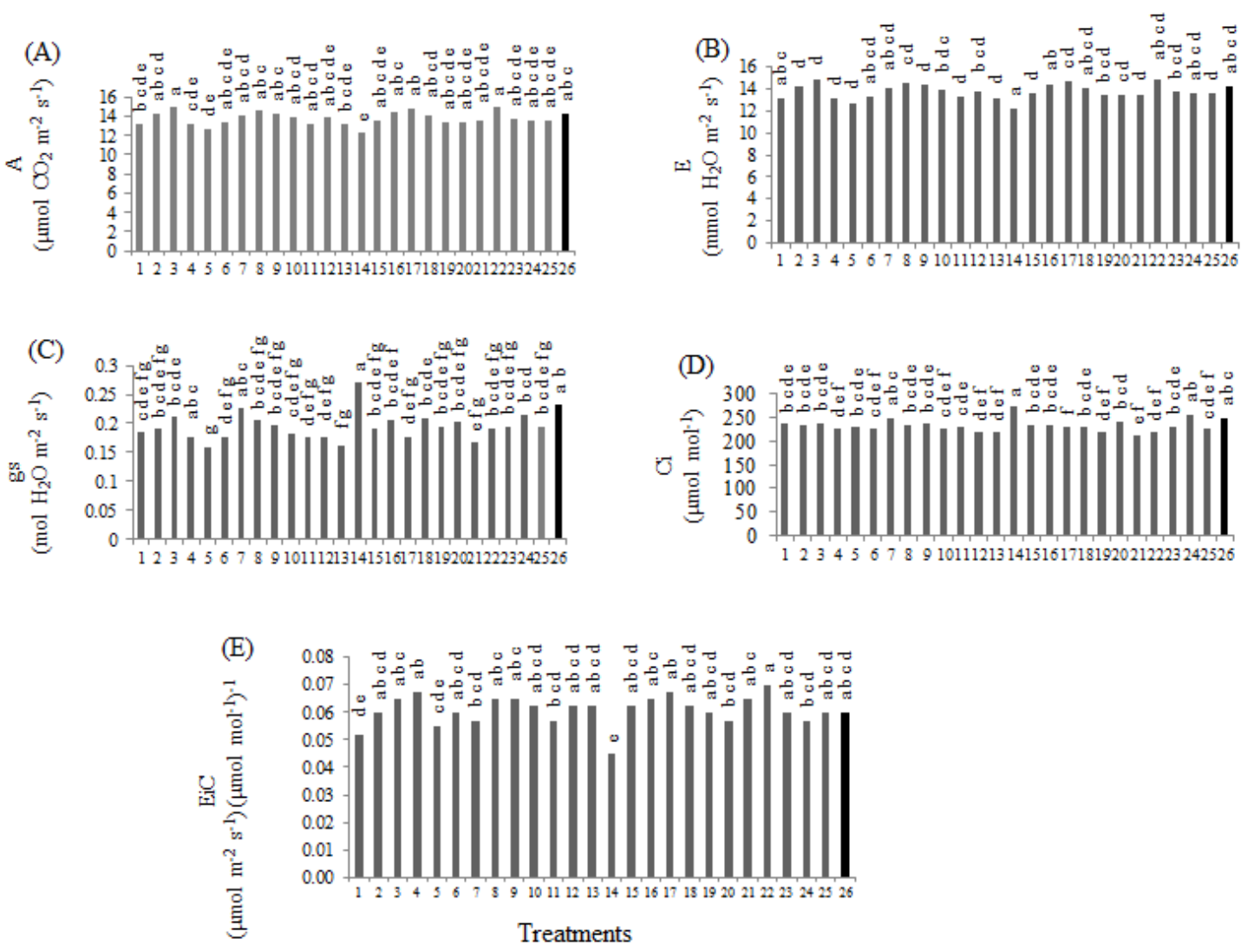

Figure 1. Gas exchange: photosynthesis (A), transpiration (B), stomatal conductance (C), internal $\mathrm{CO}_{2}$ concentration (D) and instant carboxylation efficiency (E) of upland rice plants, cultivar BRS A501 CL, treated with multifunctional microorganisms, isolated or mixed (Numbers 1 to 26). * Means followed by the same letter do not differ by the LSD test (p $<0.05$ ). The black column refers to the control treatment (without application of the microorganism). Burkholderia pyrrocinia isolates (BRM 32113) (1); Pseudomonas fluorescens (BRM 32111) (2); Pseudomonas sp. (BRM 32112) (3); Serratia sp. (BRM 32114) (4); Bacillus sp. (BRM 32110) (5); Bacillus sp. (BRM 32109) (6); Pool of T. asperellum (7); Azospirillum brasilense (Ab-V5) (8); Azospirillum sp. (1381) (9); Bacillus spp. (1301) (10), Mix treatments BRM $32114+$ BRM 32110 (11); BRM 32114 + Ab-V5 (12); BRM 32114 + Pool of T. asperellum (13); BRM 32110 + Ab-V5 (14); BRM $32110+$ Pool of T. asperellum (15); Ab-V5 + Pool of T. asperellum (16); $1381+1301$ (17); $1381+\mathrm{Ab}-\mathrm{V} 5$ (18); $1301+\mathrm{Ab}$ -V5 (19); 1381 + BRM 32114 (20); 1301 + BRM 32114 (21); 1381 + BRM 32110 (22); 1301 + BRM 32110 (23); 1381 + Pool of T. asperellum (24); $1301+$ Pool of T. asperellum (25) and the control treatment (without microorganism) (26).

In the dry root biomass, the greatest increases occurred with upland rice plants treated with the isolate A. brasiliense, Serratia sp. + pool of $T$. asperellum and $1301+$ BRM 32110 , which differed significantly from the control treatment (Figure 2). In relation to the total dry biomass variable (shoot + root), greater increments were found in plants treated with the multifunctional microorganisms BRM $32114+$ pool of $T$. asperellum, despite not statistically differing from the control treatment. It is observed, therefore, that the largest increases in dry biomass and tillers were detected in rice plants treated with multifunctional microorganisms in mix. For total dry biomass (whole plant), the treatments that provided the greatest increase were BRM 32114 + pool of T. asperellum, $1301+\mathrm{Ab}-\mathrm{V} 5$ and $1301+$ BRM 32110, which differed significantly from the control treatment, but did not differ from treatments $1381+$ pool of $T$. asperellum and $1301+T$. asperellum. In research developed by Banayo et al. (2012), it was also possible to verify beneficial effects in plants treated with multifunctional microorganisms (Azospirillum and Trichoderma). According to the researcher, these microorganisms positively influenced the increase in the production of biomass and grain yield in the rice crop by producing growth hormones and stimulating greater root development and greater absorption of nutrients, with direct effects on the development of the plant. Likewise, the bioagent Bacillus sp. was able to stimulate the development and yield in the pepper crop, and Trichoderma sp. provided greater biomass of roots in the cucumber crop (YEDIDIA et al., 2001; HERMAN; NAULTB; SMART, 2008). 

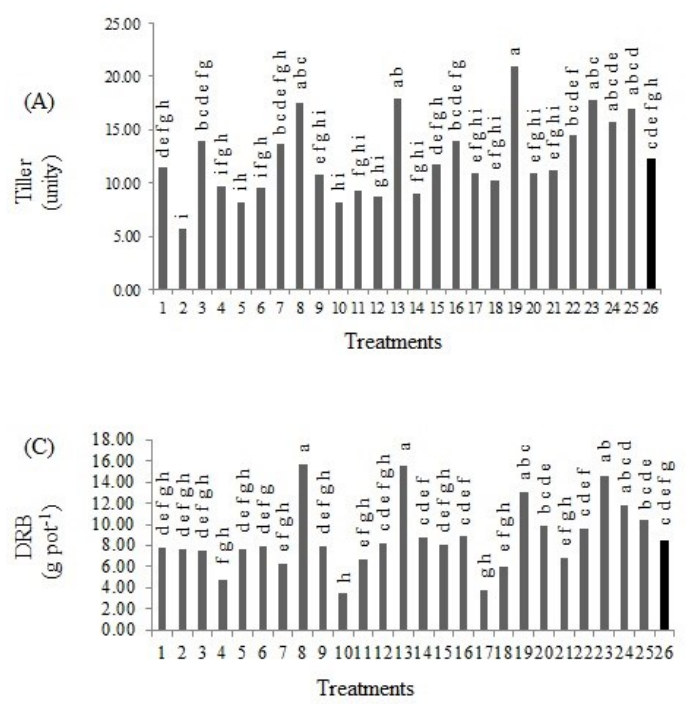
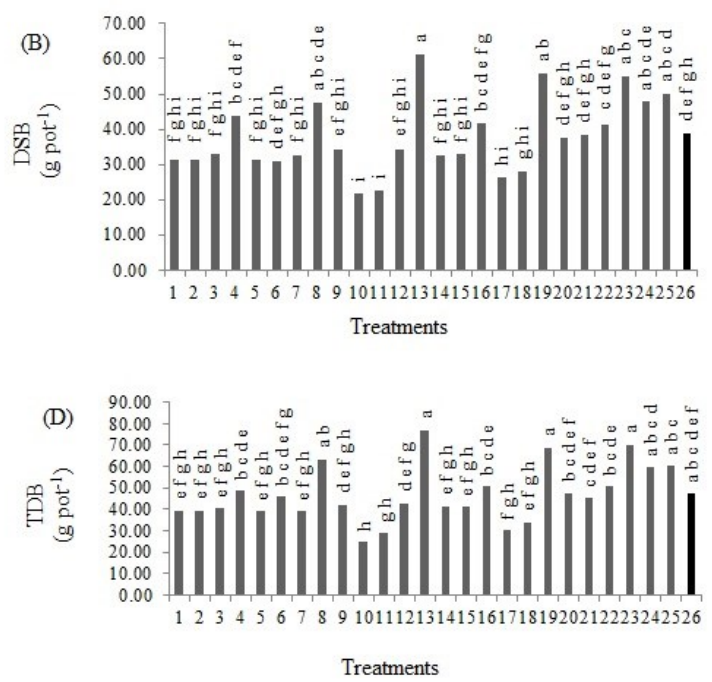

Figure 2. Number of tillers (TILLER, A), dry shoot biomass (DSB, B), dry root biomass (DRB, C) and total dry biomass (TDB, D) of upland rice plants, cultivate BRS A501 CL, treated with multifunctional microorganisms, isolated or mixed. (Numbers 1 to 26). * Means followed by the same letter do not differ by the LSD test $(\mathrm{p}<0.05)$. The black column refers to the control treatment (without application of the microorganism). Burkholderia pyrrocinia isolates (BRM 32113) (1); Pseudomonas fluorescens (BRM 32111) (2); Pseudomonas sp. (BRM 32112) (3); Serratia sp. (BRM 32114) (4); Bacillus sp. (BRM 32110) (5); Bacillus sp. (BRM 32109) (6); Pool of T. asperellum (7); Azospirillum brasilense (Ab-V5) (8); Azospirillum sp. (1381) (9); Bacillus spp. (1301) (10), Mix treatments BRM 32114 + BRM 32110 (11); BRM 32114 + AbV5 (12); BRM 32114 + Pool of T. asperellum (13); BRM $32110+$ Ab-V5 (14); BRM 32110+ Pool of T. asperellum (15); Ab-V5 + Pool of T. asperellum (16); 1381 + 1301 (17); $1381+$ Ab-V5 (18); $1301+$ Ab-V5 (19); 1381 + BRM 32114 (20); 1301 + BRM 32114 (21); 1381 + BRM 32110 (22); 1301 + BRM 32110 (23); 1381 + Pool of T. asperellum (24); 1301 + Pool of T. asperellum (25) and the control treatment (without microorganism) (26).

The largest accumulations of $\mathrm{N}, \mathrm{P}$ and $\mathrm{K}$ in the shoots were observed in rice plants treated with the mixed application of the microorganisms BRM 32114 + BRM 32110 (Figure 3). However, this treatment provided a significant difference only for $\mathrm{N}$ and $\mathrm{P}$ accumulations in rice plants, and for nutrient $\mathrm{K}$ it did not differ significantly from the control treatment. In terms of nutrient accumulation in the root system, treatment 1301 + BRM 32110 stands out, which provided a greater increase in nutrients $\mathrm{N}$ and $\mathrm{P}$ (12 and $98 \%$, respectively) compared to the control treatment, however, there was a significant difference in relation to control treatment only for nutrient $\mathrm{P}$. The highest accumulation of $\mathrm{K}$ in the root system was obtained with plants treated with $1381+$ Pool of T. asperellum, which differed significantly from the control treatment. Based on our results, it appears that, in general, treatments containing mix of microorganisms provided greater gains in nutritional accumulation in rice plants, which allows us to infer that the use of mixture of microorganisms is promising and provides better results than application of only one microorganism. This technology called coinoculation is already commonly used in soybean crop. Mauricio Filho, Silva and Souza (2018) found higher production of dry biomass in soybean plants when treated with
Azospirillum $\mathrm{sp}$ and Bradyrhizobium sp. coinoculated than with standard inoculation (only Bradyrhizobium sp.).

The greater absorption and accumulation of nutrients in plants treated with multifunctional microorganisms may have occurred because they provide greater root development, which thus explores a greater volume of soil. This result is positive and may provide a reduction in the demand for synthetic fertilizers. These fertilizers are expensive, finite, have low efficiency of use by plants and can cause environmental degradation (FAGERIA, 2006; NASCENTE et al., 2017b). In this sense, the use of multifunctional microorganisms can be a viable alternative in the search for sustainable agriculture with less use of synthetic inputs. However, research must be carried out to measure the amount of fertilizers that could be saved by the use of multifunctional microorganisms. For example, Nascente et al. (2019) evaluated the microorganism Serratia sp. and nitrogen doses in upland rice crop, the authors found that with the use of the multifunctional microorganism, the grain yield of the crope was similar in the doses of $120 \mathrm{~kg} \mathrm{~N} \mathrm{ha}^{-1}$ and $80 \mathrm{~kg} \mathrm{~N} \mathrm{ha}^{-1}$, that is, provided a reduction in nitrogen fertilization by $40 \mathrm{~kg} \mathrm{ha}^{-1}$. 


(A)

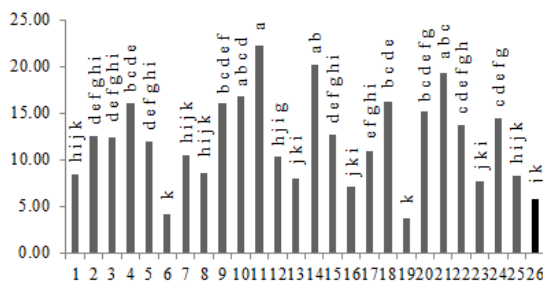

(C)

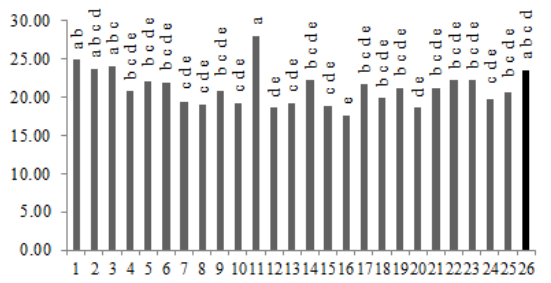

(E)

矛后

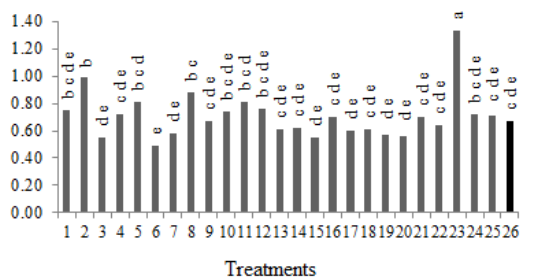

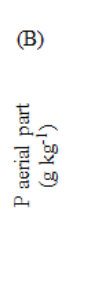

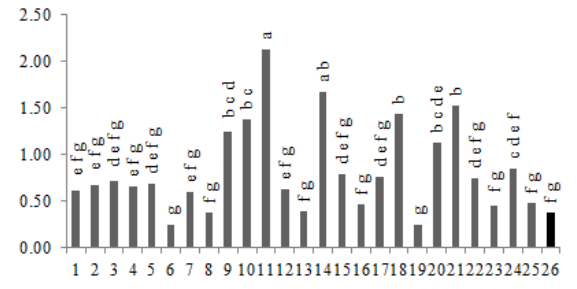

(D)

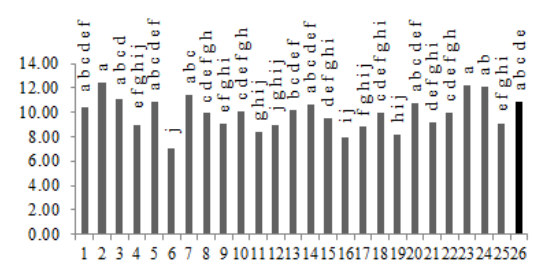

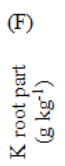

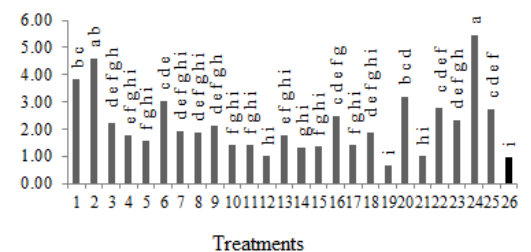

Figure 3. Content of macronutrients in $N(A), P(B), K(C)$ and $N(D), P(E), K$ (F) roots of upland rice plants, cultivar BRS A501 CL, treated with multifunctional microorganisms, isolated or mixed. (Numbers 1 to 26). * Means followed by the same letter do not differ by the LSD test $(\mathrm{p}<0.05)$. The black column refers to the control treatment (without application of the microorganism). Burkholderia pyrrocinia isolates (BRM 32113) (1); Pseudomonas fluorescens (BRM 32111) (2); Pseudomonas sp. (BRM 32112) (3); Serratia sp. (BRM 32114) (4); Bacillus sp. (BRM 32110) (5); Bacillus sp. (BRM 32109) (6); Pool of T. asperellum (7); Azospirillum brasilense (Ab-V5) (8); Azospirillum sp. (1381) (9); Bacillus spp. (1301) (10), Mix treatments BRM 32114 + BRM 32110 (11); BRM 32114 + Ab-V5 (12); BRM 32114 + Pool of $T$. asperellum (13); BRM 32110 + Ab-V5 (14); BRM 32110+ Pool of T. asperellum (15); Ab-V5 + Pool of T. asperellum (16); 1381 + 1301 (17); 1381 + Ab-V5 (18); 1301 + Ab-V5 (19); 1381 + BRM 32114 (20); 1301 + BRM 32114 (21); $1381+$ BRM 32110 (22); 1301 + BRM 32110 (23); 1381 + Pool of T. asperellum (24); $1301+$ Pool of T. asperellum (25) and the control treatment (without microorganism) (26).

The highest values in number of panicles were observed in treatments $1301+\mathrm{Ab}-\mathrm{V} 5$, Ab-V5 and BRM $32114+$ pool of Trichoderma asperellum, in the order of 2.2, 1.9 and 1.9 times higher than the number of panicles in control plants, respectively (Figure 4). In general, it is observed that the treatments that provided the highest number of tillers in the rice plants were the same that stood out for the largest number of panicles. According to Yoshida (1981), there is a positive correlation between the number of tillers and the number of panicles. For number of grains per panicle and mass of 1000 grains, the highest values were achieved in upland rice plants inoculated with 1381 and BRM 32110, with a significant difference in relation to the control. In relation to grain yield, upland rice plants inoculated with the mixed application of $1301+\mathrm{Ab}$ V5 and BRM $32114+$ Trichoderma asperellum pool were the most productive, showing an increase of $206 \%$ and $167 \%$, compared to plants of the control treatment, in addition to differing significantly. Multifunctional microorganisms interact with plants providing several positive morphological and physiological effects (MOREIRA; SIQUEIRA 2006; AVIS et al., 2008).

It was observed that for the number of panicles, the most effective treatments were $1301+$ $\mathrm{Ab}-\mathrm{V} 5, \mathrm{Ab}-\mathrm{V} 5$ and BRM $32114+$ pool of Trichoderma asperellum, respectively (Figure 4). For number of grains per panicle and mass of 1000 grains, the treatments that achieved the highest values were 1381 and BRM 32110, respectively. In grain yield, upland rice plants inoculated with the combined application of $1301+\mathrm{Ab}-\mathrm{V} 5$ and BRM $32114+$ pool of Trichoderma asperellum obtained better performance. These results allow inferring that the use of multifunctional microorganisms significantly affect the total biomass production of the plants, as well as the accumulation of nutrients in the shoots and roots, and in the yield components, resulting in significant increases in the grain yield of the crop. In addition, the mixed application of multifunctional microorganisms provided better results in rice plants. 
(A)
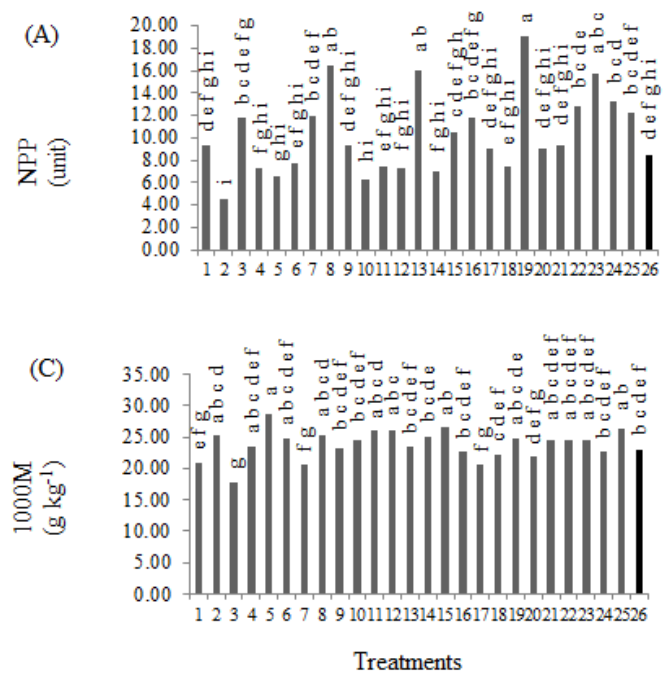

(B)
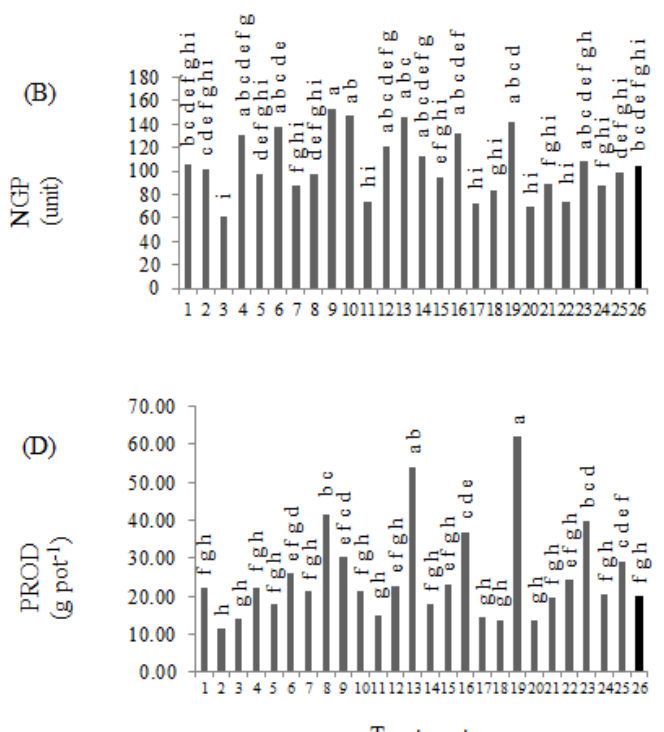

Figure 4. Number of panicles per pot (NPP, A), number of grains per panicle (NGP, B), mass of 1000 grains (1000M, C) and grain yield (PROD, D) in upland rice plants, cultivar BRS A501 CL, treated with multifunctional microorganisms, isolated or mixed. (Numbers 1 to 26). * Means followed by the same letter do not differ by the LSD test $(p<0.05)$. The black column refers to the control treatment (without application of the microorganism). Burkholderia pyrrocinia isolates (BRM 32113) (1); Pseudomonas fluorescens (BRM 32111) (2); Pseudomonas sp. (BRM 32112) (3); Serratia sp. (BRM 32114) (4); Bacillus sp. (BRM 32110) (5); Bacillus sp. (BRM 32109) (6); Pool of T. asperellum (7); Azospirillum brasilense (Ab-V5) (8) ; Azospirillum sp. (1381) (9); Bacillus spp. (1301) (10), Mix treatments BRM 32114 + BRM 32110 (11); BRM 32114 + Ab-V5 (12); BRM 32114 + Pool de T. asperellum (13); BRM 32110 + Ab-V5 (14); BRM $32110+T$. asperellum pool (15); Ab-V5 + T. asperellum pool (16); 1381 + 1301 (17); $1381+\mathrm{Ab}$-V5 (18); 1301 + Ab-V5 (19); 1381 + BRM 32114 (20); 1301 + BRM 32114 (21); 1381 + BRM 32110 (22); 1301 + BRM 32110 (23); 1381 + Pool T. asperellum (24); $1301+$ Pool of T. asperellum (25) and the control treatment (without microorganism) (26).

Regarding the analysis of the main components, it was found that the variability of treatments with isolated and mixed microorganisms in gas exchange (photosynthetic rate, transpiratory rate, stomatal conductance, internal $\mathrm{CO}_{2}$ concentration and leaf temperature), shoot biomass production, root and total (SBP, RBP and TBP), accumulation of nutrients in the shoot part (Shoot.N.total.g_kg, Shoot.P.total.g_kg and Shoot.K.total.g_kg), accumulation of nutrients in the roots (Root.N.total.g_kg, Root.P.total.g_kg and Root.K.total.g_kg) and grain yield (Total.grains) and the production components: number of panicles per pot (N.panicles), number of grains per panicle (Panicle.grains), number of tillers (N.perfilhos) and mass of 1000 grains (M1000grains) were best described by three main components (MCs), representing $62 \%$ of the data variation, that is, $\mathrm{MC} 1$ (34.52\%), MC2 (16.07\%) and MC3 (11.22\%) (Figure 5).

The factor map (biplot) shows groups of variables (arrows) denoting positive and negative correlations with each main component (MC), with the length of the arrow indicating the magnitude of each response for each MC (Figure 5). For example, MC1 was positively correlated with total dry mass, shoot dry matter and root dry mass, amount of grains, total grain mass, number of panicles and number of tillers, but it was negative with nitrogen accumulation $(\mathrm{N})$ and phosphorus $(\mathrm{P})$ in the aerial part. On the other hand, MC2 was positively correlated with the transpiratory rate (A), stomatal conductance (gs), internal $\mathrm{CO}_{2}$ concentration (Ci) and accumulation of $\mathrm{N}$ and $\mathrm{K}$ in the roots and negatively with the leaf temperature and instant efficiency of carboxylation. MC3 was positively correlated with the mass of 1000 grains and was negatively correlated with the photosynthetic rate (A) and with the instant efficiency of carboxylation (EiC). The variables of total dry biomass and shoot biomass presented the greatest contribution to $\mathrm{MC} 1$, $88 \%$ and $86 \%$, respectively. On the other hand, the internal concentration of $\mathrm{CO}_{2}$ had the greatest contribution to the variability of MC2 (86\%) and the mass of 100 grains to MC3 (65\%). 
(A) MCA1 X MCA2

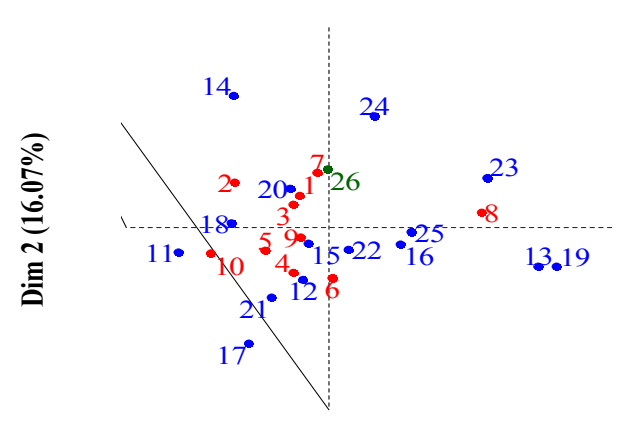

$\operatorname{Dim} 1(34.52 \%)$

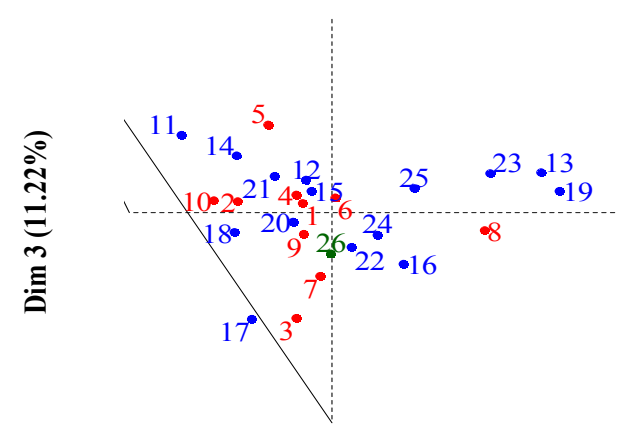

$\operatorname{Dim} 1(34.52 \%)$

(C) MCA2 X MCA3

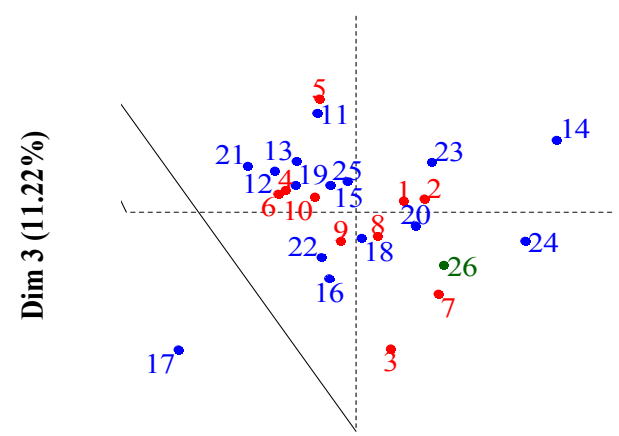

$\operatorname{Dim} 2(16.07 \%)$

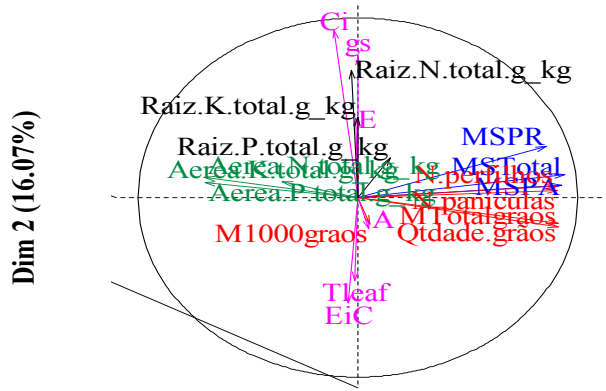

$\operatorname{Dim} 1(34.52 \%)$

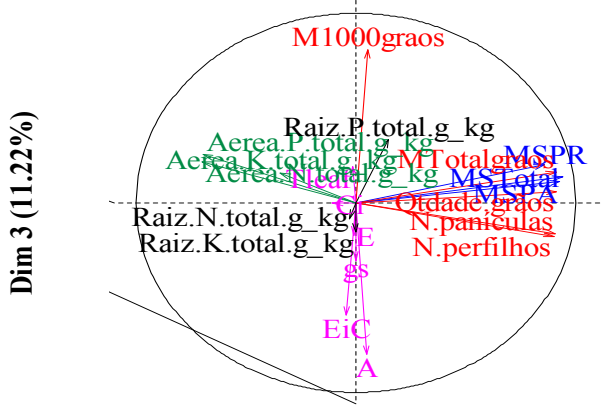

$\operatorname{Dim} 1(34.52 \%)$

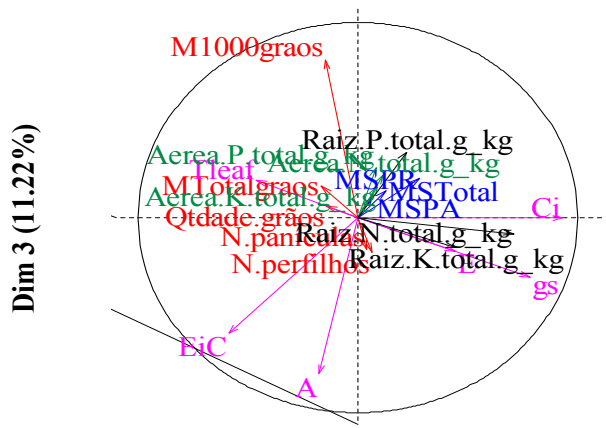

$\operatorname{Dim} 2(16.07 \%)$

Figure 5. Principal component analysis (PCA) explaining correlations between variables and between 26 treatments with isolated and mixed microorganisms. Three main components (PCs) accounted for $62 \%$ of the data variation. Treatments: isolated Burkholderia pyrrocinia (BRM 32113) (1); Pseudomonas fluorescens (BRM 32111) (2); Pseudomonas sp. (BRM 32112) (3); Serratia sp. (BRM 32114) (4); Bacillus sp. (BRM 32110) (5); Bacillus sp. (BRM 32109) (6); Pool of $T$. asperellum (7); Azospirillum brasilense (Ab-V5) (8); Azospirillum sp. (1381) (9); Bacillus spp. (1301) (10), Mix treatments BRM 32114 + BRM 32110 (11); BRM 32114 + Ab-V5 (12); BRM 32114 + Pool of T. asperellum (13); BRM 32110 + AbV5 (14); BRM 32110+ Pool of T. asperellum (15); Ab-V5 + Pool of T. asperellum (16); $1381+1301$ (17); $1381+$ Ab-V5 (18); 1301 + Ab-V5 (19); 1381 + BRM 32114 (20); 1301 + BRM 32114 (21); 1381 + BRM 32110 (22); 1301 + BRM 32110 (23); $1381+$ Pool of T. asperellum (24); $1301+$ Pool of T. asperellum (25) and the control treatment (without microorganism) (26).

Rev. Caatinga, Mossoró, v. 33, n. 3, p. 679 - 689, jul. - set., 2020 
Based on the representational quality of treatments with isolated microorganisms and in mix for the analyzed variables, the treatments BRM $32114+$ Pool of T. asperellum (13), $1301+$ Ab-V5 (19) and $1301+$ BRM 32110 (23) presented the greater positive correlation for the variables shoot biomass, root biomass, total biomass, mass of 1000 grains and quantity of grains per panicle (Figure 1). The variables number of tillers and number of panicles correlated with the isolated Bacillus sp. BRM 32109 (6). The treatment BRM $32110+$ AbV5 (14) correlated with the internal concentration of $\mathrm{CO}_{2}$ and the Pool of $T$. asperellum (24) with stomatal conductance (gs) and $\mathrm{N}$ accumulation in the root. The accumulation of $\mathrm{P}$ in the root was positively correlated with the treatment Pseudomonas fluorescens (BRM 32111) (2) and the accumulation of $\mathrm{K}$ in the root with the control treatment (26). The accumulation of $\mathrm{N}, \mathrm{P}$ and $\mathrm{K}$ in the rice shoots was correlated with the treatments Bacillus sp. (10), BRM $32114+$ Ab-V5 (12) and $1301+$ BRM 32114 (21).

Considering the results obtained in this research, it appears that the use of this biodiversity of multifunctional microorganisms existing in soils, mainly in the mixture of two multifunctional microorganisms, strongly contributes to the significant increase in the development of plants, which can be observed in the greatest tillering, in the greater production of biomass, in the greater absorption and accumulation of nutrients, in the increase of yield components and in the grain yield of rice, and thus in the achievement of sustainable agriculture. However, new studies must be done under field conditions to validate the good results achieved under controlled conditions.

\section{CONCLUSIONS}

The use of mix of multifunctional microorganisms was more effective in potentiating the beneficial effects than microorganisms applied alone in upland rice plants; The treatments $1301+$ Ab-V5 and BRM $32114+$ pool of Trichoderma asperellum were the most effective in providing better development of rice plants, resulting in higher numbers of tillers, shoot, root and total biomass, resulting in greater crop grain yield.

\section{ACKNOWLEDGMENT}

To Embrapa Rice and Beans for the support and concession of the study area. To the Embrapa researcher Dr. Enderson Petrônio de Brito Ferreira for making part of his collection of microorganisms available for the development of the experiment. To the professionals who help in conducting the experiment Dr. Fábio José Gonçalves, Ms. Marina Teixeira Arriel, Adriana Mendonça Barbosa, Antônio da Conceição Teixeira, Nelson Tavares de Barros Junior and Ms. João Antônio Mendonça. To the team at the Microbiology and Phenotyping laboratories. To $\mathrm{CNPq}$ for the research productivity grant to the second and third authors. To CNPq (process number 406507/2018-0) and to FAPEG (process number 201410267001713) for research funding.

\section{REFERENCES}

AVIS, T. J. et al. Multifaceted beneficial effects of rhizosphere microorganisms on plant health and productivity. Soil Biology and Biochemistry, 40: 1733-1740, 2008.

BANAYO, N. P. M. et al. Evaluation of Biofertilizers in Irrigated Rice: Effects on Grain Yield at Different Fertilizer Rates. Agriculture, 2: 73-86, 2012.

DEVKOTA, K. P. et al. Economic and environmental indicators of sustainable rice cultivation: A comparison across intensive irrigated rice cropping systems in six Asian countries. Ecological Indicators, 105: 199-214, 2019.

DONAGEMA, G. K. et al. Manual de métodos de análise de solo. 2 ed. Rio de Janeiro,

RJ: Embrapa Solos, 2011, 230 p.

EMPRESA BRASILEIRA DE PESQUISA AGROPECUÁRIA - EMBRAPA. BRS A501 CL: Cultivar de Arroz de Terras Altas Resistente a Herbicida. 1 ed. Santo Antônio de Goiás, GO: Embrapa Arroz e Feijão, 2018. 8 p.

EMPRESA BRASILEIRA DE PESQUISA AGROPECUÁRIA - EMBRAPA. Dados de conjuntura da produção de arroz no Brasil (19862017). Disponível em:. <http:// www.cnpaf.embrapa.br/socioeconomia/docs/arroz/ dadosConjunturais arroz brasil.htm>. Acesso em: 08 out. 2019.

FAGERIA, N. K. A cultura do arroz no Brasil. 2. ed. Santo Antônio de Goiás, GO: Embrapa Arroz e Feijão, 2006. 387 p.

FILIPPI, M. C. C. et al. Leaf blast (Magnaporthe oryzae) suppression and growth promotion by rhizobacteria on aerobic rice in Brazil. Biological Control, 58: 160-166, 2011.

FRANÇA, S. K. S. et al. Biocontrol of sheath blight by Trichoderma asperellum in tropical lowland rice. Agronomy for Sustainable Development, 35: 317- 
$324,2015$.

GODFRAY, H. C. J. et al. The Challenge of food Security. Science, 327: 812-818, 2012.

HERMAN, M. A. B.; NAULTB, B. A.; SMART, C. D. Effects of plant growth-promoting rhizobacteria on bell pepper production and green peach aphid infestations in New York. Crop Protection, 27: 9961002, 2008.

KADO, C. J.; HESKETT, M. G. Selective media for isolation of Agrobacterium, Corynebacterium, Erwinia, Pseudomonas and Xanthomonas. Phytopathology, 60: 969-976, 1970.

KASSAMBARA, A. Factoextra: Extract and Visualize the Results of Multivariate Data

Analyses. Disponível em: <http://www.sthda.com>. Acesso em: 03 de mai 2020.

MALAVOLTA, E.; VITTI, G. C.; OLIVEIRA, S. A. Avaliação do estado nutricional das plantas: princípios e aplicações. 2. ed. Piracicaba, SP: Associação Brasileira para Pesquisa da Potassa e do Fosfato. 1997. 221 p.

MATOSO, E. S. et al. Influência do uso de um mix de bactérias diaztróficas na biometria e no conteúdo de clorofila de plantas de cana-de-açúcar. Brazilian Journal of Developenent, 6: 7261-7274, 2020.

MAURICIO FILHO, J. M.; SILVA, C. H. S.; SOUZA, J. E. B. Desempenho agronômico e produtividade da cultura da soja com a coinoculação de Bradyrhizobium e Azospirillum brasilense. Ipê Agronomic Journal, 2: 48-59, 2018.

MOREIRA, F. M. S; SIQUEIRA, J. O. Microbiologia e Bioquímica do Solo. 2. Ed. Lavras, MG: Editora UFLA, 2006. 729 p.

NASCENTE, A. S. et al. Biomass, gas exchange, and nutrient contents in upland rice plants affected by application forms of microorganism growth promoters. Environmental Science and Pollution Research, 24: 2956-2965, 2017a.

NASCENTE, A. S. et al. Effects of beneficial microorganisms on lowland rice development. Environmental Science and Pollution Research, 24: 25233-25242, $2017 \mathrm{~b}$.

NASCENTE, A. S. et al. N Fertilizer DoseDependent Efficiency of Serratia spp. for Improving Growth and Yield of Upland Rice (Oryza sativa L.). International Journal of Plant Production, 13: 2017-226, 2019.
OLIVEIRA, et al. Formas e tipos de coinoculação na cultura da soja no Cerrado. Revista de Ciências Agrárias, 42: 924-932, 2019.

SANTOS, H. G. et al. Sistema Brasileiro de Classificação de Solos. 5. ed. Brasília, DF: Embrapa, 2018. 355 p.

SILVA, J. C. et al. Biocontrol of sheath blight on rice and growth promotion by Trichoderma isolates from the Amazon. Revista de Ciências Agrárias, 55: 243-250, 2012.

SILVA, M. A. et al. Photosynthetic capacity and water use efficiency in sugarcane genotypes subject to water deficit during early growth phase. Brazilian Archives of Biology and Technology, 56: 735-748, 2013.

SILVA, V. N. et al. Promoção de crescimento e indução de resistência à antracnose por Trichoderma spp. em pepineiro. Pesquisa Agropecuária Brasileira, 46: 1609-1618, 2011.

SOUSA, I. M.; NASCENTE, A. S.; FILIPPI, M. C. C. Bactérias promotoras do crescimento radicular em plântulas de dois cultivares de arroz irrigado por inundação. Colloquium Agrariae, 15: 140-145, 2019.

SPERANDIO, E. M. et al. Evaluation of rhizobacteria in upland rice in Brazil: growth promotion and interaction of induced defense responses against leaf blast. Acta Physiologiae Plantarum, 39: 1-11, 2017.

YEDIDIA, I. et al. Effect of Trichoderma harzianum on microelement concentrations and increased growth of cucumber plants. Plant Soil, 235: 235242,2001

YOSHIDA, S. Fundamentals of rice crop science. Los Baños, Laguna: IRRI, 1981, 269 p. 